\title{
Do We Really Need More Proof before EUS-FNA Is Considered the Gold Standard for Lymph Node Staging of the Mediastinum?
}

\author{
Søren S. Larsen Peter Vilmann \\ Gentofte Hospital, Department of Surgical Gastroenterology D, University of Copenhagen, Hellerup, Denmark
}

With the introduction of multi-modality treatment of non-small cell lung cancer (NSCLC), exact staging of the disease has become increasingly important. It is generally accepted that a suspicion of mediastinal spread needs to be verified by sampling of tissue, before a patient can be rejected for surgery with curative intention. Transbronchial needle aspiration biopsy (TBNA) is a safe and minimally invasive method performed during initial bronchoscopy. The false negative rate is, however, high, and further invasive staging is often needed if CT has demonstrated enlarged mediastinal lymph nodes. Until recently, mediastinoscopy and open thoracotomy was the next diagnostic step for such patients, but during the past decade, growing evidence of the value of endoscopic transoesophageal ultrasound-guided fine-needle aspiration biopsy (EUS-FNA) has emerged [1].

The study of Annema et al. [2] in this issue of Respiration focused on NSCLC patients with enlarged subcarinal lymph nodes and a negative TBNA. In 10 of 14 of these patients, EUS-FNA demonstrated mediastinal malignancy, thus avoiding further invasive procedures. No false negative diagnoses and no complications were experienced. The study is in agreement with the literature showing that EUS-FNA is highly accurate for lymph node staging of enlarged lymph nodes in the mediastinum located adjacent to the oesophagus and outlined by CT.
There is, however, still room for questions and scepticism. First, most of the recent studies have been retrospective, not consecutive, and seem to have been performed in selected patients. Second, no true blinding between different modalities has been performed comparing EUS-FNA, mediastinoscopy and TBNA. Third, most of the published results are from expert centres. If EUSFNA is taken up by all groups involved in lung cancer staging, how would this affect the diagnostic yield? When all this is said, there is still much evidence that speaks in favour of EUS-FNA as a safe and minimally invasive tissue sampling method in patients with enlarged mediastinal lymph nodes outlined by CT.

However, what about lung cancer patients without enlarged lymph nodes? In our own experience, EUS-FNA is able to demonstrate mediastinal lymph node metastases in a number of patients without enlarged mediastinal lymph nodes on CT. This impression is supported by limited experience from two studies in which EUS-FNA demonstrated mediastinal malignancy in 10 of $24(42 \%)$ and in 4 of $18(22 \%)$ CT-negative patients, respectively [3, 4]. A further step forward would be a randomized trial comparing a staging strategy with EUS-FNA in NSCLC patients with a conventional strategy without EUS-FNA.

At present, mediastinoscopy is still considered complementary to EUS-FNA since EUS-FNA cannot visualise

\begin{tabular}{ll}
\hline KARGER & ( ) 2004 S. Karger AG, Basel \\
Fax +4161306 1234 $34-7931 / 04 / 0716-0555 \$ 21.00 / 0$ \\
$\begin{array}{l}\text { E-Mail karger@karger.ch } \\
\text { www.karger.com }\end{array}$ & $\begin{array}{l}\text { Accessible online at: } \\
\text { www.karger.com/res }\end{array}$
\end{tabular}

Dr. Peter Vilmann

Gentofte Hospital, Department of Surgical Gastroenterology D

University of Copenhagen, Niels Andersens Vej 55

DK-2900 Hellerup (Denmark)

Tel. +45 397779 50, Fax +45 3977 76 29, E-Mail pevi@gentoftehosp.kbhamt.dk 
structures anterior to the air-filled trachea and main bronchi. Endoscopic transbronchial real-time ultrasoundguided biopsy (EBUS-TBNA) performed via the trachea and main bronchi could be a less invasive alternative to mediastinoscopy. Preliminary results with a prototype
EBUS-TBNA bronchoscope have demonstrated promising results [5]. Hopefully, the combination of EUS-FNA and EBUS-TBNA will be able to replace more invasive and risky staging methods and improve the $\mathrm{N}$-staging accuracy in the mediastinum and lung hilar regions.

\section{References}

1 Larsen SS, Krasnik M, Vilmann P, Jacobsen GK, Petersen JH, Fauerskov P, Folke K: Endoscopic ultrasound guided biopsy of mediastinal lesions has a major impact on patient management. Thorax 2002;57:98-103.

2 Annema JT, Veseliç M, Rabe KF: Analysis of subcarinal lymph nodes in (suspected) nonsmall-cell lung cancer after a negative transbronchial needle aspiration - what's next? Respiration 2004;71:630-634.

- 3 Wallace MB, Silvestri GA, Sahai AV, Hawes RH, Hoffman BJ, Durkalski V, Hennesey WS, Reed CE: Endoscopic ultrasound-guided fine needle aspiration for staging patients with carcinoma of the lung. Ann Thorac Surg 2001;72: 1861-1867.
-4 Fritscher-Ravens A, Bohuslavizki KH, Brandt L, Bobrowski C, Lund C, Knofel WT, Pforte A: Mediastinal lymph node involvement in potentially resectable lung cancer: Comparison of $\mathrm{CT}$, positron emission tomography, and endoscopic ultrasonography with and without fineneedle aspiration. Chest 2003;123:442-451.

5 Krasnik M, Vilmann P, Larsen SS, Jacobsen GK: Preliminary experience with a new method of endoscopic transbronchial real-time ultrasound guided biopsy for diagnosis of mediastinal and hilar lesions. Thorax 2003;58: 1083-1086. 